Brit. F. industr. Med., 1967, 24, 333.

\title{
Miscellanea
}

\section{Lead Poisoning in Jewellery Enamellers}

\author{
R. FOTHERGILL, M. D. KIPLING, and A. B. WEBER \\ From the East Birmingham Hospital and H.M. Medical Inspector of Factories
}

Lead poisoning in jewellery enamellers in Birmingham has been described both at the beginning of this century and again in recent years. The condition arises from the habit of some workers of placing the enamel applicator in the mouth. The history of the hazard is reviewed and an investigation described.

'About the cleanest workpeople in Birmingham are the jewellers.'

A. Wolfe (1901)

\section{Process}

The manufacture of jewellery is an old-established industry in Birmingham which is still carried out in the jewellery quarter of the town where jewellery and badges are enamelled by women in well-lit workshops, some of which retain the graceful features of early industrial architecture. At the work bench the enamel is contained in a small jar, and the designs, which are often small and complicated crests on medals and cuff links, are painted on the jewellery with a metal applicator. Skill and training are necessary to master the craft which, when acquired, provides very satisfying work. The enamel frit used in the process is a lead-borosilicate containing about $42 \%$ of lead. It is insoluble in water but partially soluble in $0.1 \mathrm{~N}$ hydrochloric acid, Io mg. of the powder yielding about $100 \mu \mathrm{g}$. of lead in solution after incubation for one hour at $37^{\circ} \mathrm{C}$. (Chalmers, Whitehead, and Massey, 1963), a test devised to resemble both the conditions in the human stomach and that statutorily prescribed in the Pottery (Health) Special Regulations, 1947.

\section{Historical Review}

Anderson and Legge (1903), in a survey of vitreous enamelling, examined 44 male and 31 female jewellery enamellers. They diagnosed lead poisoning in ro workers who showed a blue line on the gums and in another eight with clinical signs of anaemia. Their report is as true now as when it was written: 'Enamelling of jewellery is carried on

Received for publication April 13, 1967. in a number of small workshops in Birmingham to which the materials ready to receive the enamel are sent out by other firms, to whom they are returned when enamelled. From the small amount of enamel used in the processes it would at first sight appear absurd to expect evidence of plumbism and yet two undoubted cases have been reported-both in 1901 . Further examination of the workers, although the number examined is not large, shows that some risk is run. The persons employed, many of them female young persons, work fairly close together, often grouped round a small table. A little of the enamel powder dries into dust on the table. It is not from this source generally that in our opinion the poisoning arises, but almost entirely from the habit which some thoughtless workers develop of putting into their mouth the little implement used for lifting the enamel and placing it in the interstices of the metal. The point is one on which it would be advisable to warn workers-especially the young'. It is possible to differ from the authors to the extent that placing the implement in the mouth is not always due to thoughtlessness; many find that saliva is of great help in applying the enamel.

Their investigation showed that plumbism in jewellery enamellers did not compare in severity or incidence with that occurring in the enamelling of iron and glass and therefore the enamelling of jewellery or watches is specifically exempted from the application of the Vitreous Enamelling Regulations 1908 that followed this survey. There was a further case of poisoning described by Harding (1906) which he qualified by the statement 'This man, however, was a heavy beer drinker and may have imbibed lead with his early morning beer'. 
No more cases were reported until 1962 when a young woman was admitted to the Queen Elizabeth Hospital, Birmingham, for investigation of attacks of nausea, colic, and constipation for which two years previously her appendix (histologically normal) had been removed and for which she had received gynaecological treatment in hospital. The finding of a haemoglobin of $7.9 \mathrm{~g} . / 100 \mathrm{ml}$. with marked stippling of the red cells, a considerably increased excretion of urinary coproporphyrins and a urinary lead of $289 \mu \mathrm{g} . / 24 \mathrm{hrs}$. established a diagnosis of lead poisoning. This case provided an excellent illustration of the difficulties that may arise in the diagnosis of sporadic lead poisoning because her family doctor, who was also an appointed factory doctor and well aware of the symptomatology of lead poisoning, was misled by her original description of herself as an office worker, and the treatment given in hospital each time appeared to be successful-removal from work causing a cessation of the symptoms. When a diagnosis had been made, enquiries into her occupational history showed that for three years from the age of 15 in her work as badge enameller she had been in the habit of putting the applicator in her mouth (mouth pointing). Following this a survey of 223 jewellery enamellers was undertaken (Chalmers et al., 1963; and one of us (M.D.K.)).

Three further cases of lead poisoning with marked anaemia and abdominal symptoms, one of whom had undergone appendicectomy, were discovered. Mouth pointing was practised regularly by $18 \%$ of the women, and another $40 \%$ practised it on occasions. Of the regular mouth pointers, $35 \%$ had haemoglobin levels below I2 g./100 ml. and $20 \%$ showed excess urinary porphyrins. These results may be compared with those of the group who denied mouth pointing, of whom $10.5 \%$ had haemoglobin levels below $12 \mathrm{~g}$./100 $\mathrm{ml}$. and none showed excess urinary porphyrins. After this survey, in which it was considered that the great majority of jewellery enamellers were examined, it was confidently expected that the hazards of mouth pointing had been fully realized and the practice abandoned. However, in 1966, a 15-year-old girl, after spending three months in a workshop employing five other girls, was admitted to the East Birmingham Hospital.

\section{Case Report}

D.B. aged 15 was admitted to hospital on 5 October 1966 complaining of constant nausea, occasional vomiting, anorexia, constipation, and lethargy for the past three weeks. She had also noticed high colouration of her urine. Because of these complaints and because she appeared jaundiced she was admitted to the infectious disease unit of East Birmingham Hospital with the diagnosis of suspected infectious hepatitis.

Physical examination revealed extreme pallor, slightly icteric conjunctivae, and tenderness in the epigastrium, but no other abnormality. Liver, spleen, and lymph nodes were not palpable.

Laboratory Investigations $\mathrm{Hb} 7.8 \mathrm{~g} . / 100 \mathrm{ml}$., M.C.H.C. $33 \%$, W.B.C. $8,500 /$ c. mm. (normal distribution), platelets normal; stained blood smears showed normochromic red cells with an anisopoikilocytosis and marked coarse punctate basophilic stippling. The reticulocytes were $10 \%$ to $18 \%$. Stippled cells 15,000 per million red cells. Serum bilirubin $1.5 \mathrm{mg}$./ $100 \mathrm{ml}$. Alkaline phosphatase 8 units per $100 \mathrm{ml}$; thymol turbidity less than I unit; glutamic oxalacetic transaminase 22 units per ml.; glutamic pyruvate transaminase 20 units per $\mathrm{ml}$., albumin $5.0 \mathrm{~g}$./100 ml.; globulin $2.4 \mathrm{~g} . / 100 \mathrm{ml}$. The urine contained an increased amount of urobilinogen and urobilin and coproporphyrins. Blood lead was $77 \mu \mathrm{g}$./100 ml. (I44.5 $\mu \mathrm{g}$./ 100 $\mathrm{ml}$. corrected for $\mathrm{Hb}$ value $14.6 \mathrm{~g} . / 100 \mathrm{ml}$.). Bone marrow aspiration showed marked erythroid hyperplasia with coarse basophilic stippling in the normoblasts. Iron staining of the marrow smears revealed ring sideroblasts.

TABLE

Pathological Findings in Three Girls employed in JeWellery Enamelling

\begin{tabular}{|c|c|c|c|c|c|c|c|c|}
\hline Subject & Age & $\begin{array}{c}\text { Blood Lead } \\
(\mu \mathrm{g} . / \mathrm{roo} \mathrm{ml} .)\end{array}$ & $\begin{array}{c}\text { Blood Lead } \\
(\mu \mathrm{g} . / \mathrm{roo} \mathrm{ml} \text {. } \\
\text { corrected } \\
\text { for Hb } \\
14.6 \mathrm{~g} . / 100 \mathrm{ml} .)\end{array}$ & $\frac{H b}{(g . / 100 \mathrm{ml} .)}$ & $\begin{array}{l}\text { Urine Lead } \\
\text { ( } \mu \text { g. per litre } \\
\text { corrected for } \\
\text { Sp. G. IOI6) }\end{array}$ & $\begin{array}{c}\text { Coproporphyrin } \\
\text { Qualitative }\end{array}$ & $\begin{array}{l}\mu g . \text { per litre } \\
\text { corrected for } \\
\text { Sp. G. IOI6 }\end{array}$ & $\begin{array}{c}A L A \text { ( } \mu g . \\
\text { per litre } \\
\text { corrected for } \\
\text { Sp. G. IoI6) }\end{array}$ \\
\hline $\begin{array}{l}\text { B.C. } \\
\text { I.L. } \\
\text { C.T. }\end{array}$ & $\begin{array}{l}17 \\
15 \\
15\end{array}$ & $\begin{array}{l}62 \\
73 \\
56\end{array}$ & $\begin{array}{l}91 \cdot 7 \\
94 \cdot 3 \\
64 \cdot 4\end{array}$ & $\begin{array}{r}9 \cdot 9 \\
11 \cdot 3 \\
12 \cdot 7\end{array}$ & $\begin{array}{l}156 \\
196 \\
179\end{array}$ & $\begin{array}{r}++ \\
++ \\
+\end{array}$ & $\begin{array}{r}500 \\
1,145 \\
244\end{array}$ & $\begin{array}{l}\text { N.E. } \\
52 \\
9 \cdot 4\end{array}$ \\
\hline
\end{tabular}

N.E. = Not estimated. 
Serum iron was IIg $\mu \mathrm{g} . / 100 \mathrm{ml}$. and iron binding capacity $325 \mu \mathrm{g} . / 100 \mathrm{ml}$. \% Saturation 36. Radiographs of bones were reported as normal. The diagnosis of lead poisoning was made, and she was treated with penicillamine hydrochloride, $300 \mathrm{mg}$. t.d.s. for five days, ferrous sulphate tablets, $200 \mathrm{mg}$. t.d.s. for 15 days, and folic acid tablets, 5 mg. t.d.s.

Progress was satisfactory and she was symptom-free after this treatment. Two months after admission her haemoglobin had risen to $13.9 \mathrm{~g} . / 100 \mathrm{ml}$.

Three of the other girls employed showed pathological evidence of plumbism though no symptoms had occurred. The findings are summarized in the Table.

\section{Discussion}

As far as we know, lead poisoning in jewellery enamellers has only been described in Birmingham and occurs in an occupation in which it would not be generally expected because of the relative insolubility of the lead compound and the small quantities used. We think, therefore, that there should be awareness in other centres of the jewellery and badge enamelling trade of the risk, which may cause poisoning of some severity and may occur after short exposure. There seems little reason to doubt that in Birmingham between the investigations of 1902 and 1962 there must have been a number of these workers diagnosed, through ignorance of the lead risk, as suffering from anaemia, appendicitis or a gynaecological condition.

We are indebted to Dr. S. G. Rainsford for reports on urine tests, to Dr. H. G. Sammons for biochemical reports, to Dr. W. R. D. Seymour for information, to Dr. T. A. Lloyd Davies for encouragement, and to Dr. R. H. B. Protheroe for his advice.

\section{REFERENCES}

Anderson, A. M., and Legge, T. M. (1903). Annual Report of the Chief Inspector of Factories and Workshops for 1902, p. 313. H.M.S.O., London.

Chalmers, J. N. M., Whitehead, T. P., and Massey, P. M. O. (1963). F. clin. Path., 16, 389.

Harding, W. E. (1906). Annual Report of the Chief Inspector of Factories and Workshops for 1906, p. 62. H.M.S.O., London.

Wolfe, A. (1901). Annual Report of the Chief Inspector of Factories and Workshops for 1900, p. 205. H.M.S.O., London.

\section{The July Issue}

The July (1967) issue contains the following papers:-

Individual Variations in Sickness Absence P. J. TAYLOR

Mortality in a Movie Projectionist Union in Boston, 1910-64 B. G. FerRIs, JR. and J. Worcester Physique and Serum Lipids of Young London Busmen in relation to Ischaemic Heart Disease R. M. Oliver

Use of the Albino Guinea-pig to Detect the Skin-sensitizing Ability of Chemicals $\quad M$. A. STEvENS Early Signs of Lead-exposure: A comparative study of laboratory tests A. DE BRUIN and $H$. HOOLBOоM

A Cooling System for Impermeable Clothing J. P. Gleeson and J. F. PisanI

Effects of Pulsed Currents on Respiration and the Heart W. R. LEE, S. ZoledziowsKi, and S. Temiyachol

Investigation of a Minor Asbestos Hazard M. C. S. Kennedy and R. Routledge

Miscellanea

Protection of Employees with Defective Vision J. P. W. Hughes and M. A. Cooke

Apparent Onset of Coal-workers' Pneumoconiosis after leaving the Mines N. K. CoNI

A New Method for Calibrating the Kofranyi-Michaelis Respirometer C. T. M. DAvIES and D. S. SHIRLING

Book Reviews

A number of copies are still available and may be obtained from the Publishing Manager, British Medical Association, Tavistock Square, W.C.I, price I8s. $6 d$. 